\title{
The Impact of Debt on Corporate Profitability: Evidence from Vietnam
}

\author{
Van Toan NGO', Thị Xuan Huong TRAM ${ }^{2}$, Ba Thanh VU ${ }^{3}$ \\ Received: August 01, 2020 Revised: October 05, 2020 Accepted: October 15, 2020
}

\begin{abstract}
The study aims to investigate the impact of debt on corporate profitability in the context of Vietnam. The paper investigates the impact of debt on corporate profitability in non-finance listed companies on the Vietnam stock market. The panel data of the research sample includes 118 non-financial listed companies on the Vietnam stock market for a period of nine years, from 2009 to 2017. The Generalized Method of Moments (GMM) is employed to address econometric issues and to improve the accuracy of the regression coefficients. In this research, corporate profitability is measured as the return of EBIT on total assets. The debt ratio is a ratio that indicates the proportion of a company's debt to its total assets. Firm sizes, tangible assets, growth rate, and taxes are control variables in the study. The empirical results show that debt has a statistically significant negative effect on corporate profitability. The result also shows this effect is stronger in a non-linear (concave) way, we show that the debt ratio has nonlinear effects on corporate profitability. From this, experimental evidence shows that the optimal debt ratio is $38.87 \%$. This evidence provides a new insight to managers of the non-finance companies on how to improve the firm's profitability with debt.
\end{abstract}

Keywords: Debt, Profitability, Optimal Debt, Non-Linear

JEL Classification Code: C33, G32, L25

\section{Introduction}

Explaining the role of debt in firms' performance is one of the primary objectives of contemporary researches for more than fifty years (Modigliani \& Miller 1958). However, this role remains a questionable subject which attracts the attention of many researchers such as Goddard, Tavakoli \& Wilson (2005), Berger \& Bonaccorsi (2006), Rao, AlYahyaee \& Syed (2007), Baum, Schäfer \& Talavera (2006), Weill (2008), Nunes, Serrasqueiro \& Sequeira (2009), Margaritis \& Psillaki (2010) and Kebewar (2012).

${ }^{1}$ First Author and Corresponding Author. Faculty of Finance Banking, University of Finance - Marketing (UFM), Ho Chi Minh City, Vietnam [Postal Address: 2/4 Tran Xuan Soan Street, Tan Thuan Tay Ward, District 7, Ho Chi Minh City, 700000, Vietnam] Email: ngotoan@ufm.edu.vn

${ }^{2}$ School of Banking, University of Economics Ho Chi Minh (UEH), Ho

Chi Minh City, Vietnam. Email: txhuong@ueh.edu.vn

${ }^{3}$ Food Farm Company Limited, Ho Chi Minh City, Vietnam.

Email: vbthanh1205@gmail.com

(c) Copyright: The Author(s)

This is an Open Access article distributed under the terms of the Creative Commons Attribution Non-Commercial License (https://creativecommons.org/licenses/by-nc/4.0/) which permits unrestricted non-commercial use, distribution, and reproduction in any medium, provided the original work is properly cited.
Indeed, researchers analyze the debt ratio and try to determine whether an optimal debt ratio exists or not. An optimal debt ratio is generally defined as the one which minimizes the cost of capital for the company while maximizing the value of the company. In other words, the optimal debt ratio is the one that maximizes the profitability of the company.

Besides, the divergence between researchers can be observed in theoretical strand of literature. Three essential theories highlight the influence of debt on corporate profitability, namely: signalling theory, agency costs theory, and the tax theory. First, according to signaling theory, debt, in the presence of asymmetric information, should correlate positively to profitability. According to the agency costs theory, there are two effects of debt on profitability, firstly it is positive in the case of agency costs of equity between shareholders and managers, secondly, it's effect is negative, resulting from the agency costs of debt between shareholders and lenders. Finally, the influence of taxation is complex and difficult to predict because it depends on the principles of tax-deductibility of interest, income tax, and non-debt tax shield.

Furthermore, the disagreement exists not only in the theoretical literature but it is also present in the empirical 
strand. A negative effect of debt on profitability was confirmed by Majumdar \& Chhibber (1999), Eriotis, Frangouli \& Ventoura-Neokosmides (2002), Goddard, Tavakoli \& Wilson (2005), Rao, Al-Yahyaee \& Syed (2007), Zeitun \& Tian (2007), Nunes, Serrasqueiro \& Sequeira (2009), Nguyen \& Nguyen (2020) and Ali \& Faisal (2020). On the other hand, Baum, Schäfer \& Talavera (2006), Berger \& Bonaccorsi (2006), Margaritis \& Psillaki (2007, 2010), ul Qayyum \& Noreen (2019) and Dinh \& Pham (2020), showed a positive influence. Mesquita \& Lara (2002), and Weill (2008) found both effects in their studies. Besides that, Berger \& Bonaccorsi (2006) and Margaritis \& Psillaki (2007) found the presence of a nonlinear effect (inverse U-shaped relationship). Finally, a nonsignificant effect was confirmed by Baum, Schäfer \& Talavera (2006) in American industrial companies.

Several factors may reveal reasons for the contradictory results in empirical studies. First, these empirical studies focus on different types of samples (countries, sectors, companies, and periods). Furthermore, researchers have used different measures of profitability as a dependent variable and various debt ratios as the independent variable. Finally, these studies applied different methodologies.

The empirical literature concerning the impact of debt on profitability leads us to make two inferences. The first one is that most of the empirical studies focused on listed companies. The second one is related to the paucity of studies on the French companies as mentioned by; Goddard, Tavakoli \& Wilson (2005), Weill (2008), Margaritis \& Psillaki (2010), and recently in Kebewar (2012). Some studies on Vietnam such as Vy (2016), An \& Tuan (2018) and Le, Mai \& Nguyen (2020) have focused on the impact of debt on profitability. These two avenues motivated our study. Moreover, current work is very important because debt is a risky choice whose consequences on corporate profitability can be considerable (e.g. the risk of bankruptcy and its consequences for the stakeholders). So, we will try to find, empirically, the effect of debt on profitability for companies listed in Vietnam. Also, to improve the precision of estimation by reducing the heterogeneity for the sizes of the companies, we studied the behavior of these firms according to their size. Moreover, we will analyze not only the linear effect of debt on profitability but also the nonlinear effect by estimating a quadratic model which takes into account the squared of the variable of debt in the equation of regression. To do this, we will implement the generalized method of moments (GMM) estimation model on a sample of 118 firms observed over the period (20092017). According to the proponents of the GMM model, it provides solutions to the problems of simultaneity bias, reverse causality (especially between profitability and debts) bias, and the conundrum of possible omitted variables.

\section{Data and Variables}

\subsection{Data Description}

The sample, which is obtained from the Thomson Reuters DataStream, consists of an unbalanced panel of 118 Vietnam companies, for the duration of 2009 to 2017. Our sample is listed on the Vietnamese stock exchange. Public enterprises has been excluded from the study because of their special political leverage. Furthermore, we do not include companies with negative equity. Also, outliers were removed according to the procedure of Mason, Gunst \& Hess (2003). Thus, data and descriptive statistics are shown in Table 1.

\subsection{Variables}

\subsubsection{Dependent variable}

According to the literature, corporate profitability can be measured by several methods. Return on assets is measured by dividing net income from operations by total capital. Besides, another measurement is done by dividing net income from operations by total assets. Profitability could be calculated by dividing earnings before interest and tax (EBIT) to the total assets. We use measures of profitability measured as the return of EBIT on total assets.

Table 1: Data and descriptive statistics

\begin{tabular}{|l|c|c|c|c|c|}
\hline Variable & Obs & Mean & Std. Dev. & Min & Max \\
\hline Profitability & 1,041 & 0.0802 & 0.0932 & -0.6473 & 0.9938 \\
\hline debt & 1,041 & 0.5119 & 0.2016 & 0.0422 & 0.9669 \\
\hline debt2 & 1,041 & 0.3027 & 0.2024 & 0.0018 & 0.9349 \\
\hline Size & 1,041 & 5.9228 & 0.6742 & 4.2407 & 7.8636 \\
\hline tang & 1,041 & 0.2070 & 0.1981 & 0.0013 & 0.9995 \\
\hline growth & 1,041 & 0.1622 & 0.3026 & -0.6742 & 3.4542 \\
\hline TAX & 1,041 & 0.1712 & 0.1564 & -1.6567 & 0.9599 \\
\hline
\end{tabular}




\subsubsection{Explanatory Variables}

Debt: In theory, debt ratio can be measured in different ways i.e. total debt ratio, debt ratio in the short, medium, and long term. In our study, we define the total debt ratio (Debt) by dividing the sum of the short and long-term debt by the total assets.

Tangibility: Tangibility has two conflicting effects on profitability. On the one hand, we expect a positive effect by Himmelberg, Hubbard \& Palia (1999); they show that tangible assets are easily monitored and provide good collateral and thus they tend to mitigate agency conflicts between shareholders and creditors. On the other hand, we predict a negative correlation, because firms with high levels of tangible assets tend to be less profitable. Firms with high levels of intangible assets (in form of liquidity) have more investment opportunities in the long term, innovation, and research and development (Deloof, 2003, Nucci, Pozzolo $\&$ Schivardi, 2005). The negative relationship between tangibility and profitability has been confirmed in several studies as Rao, Al-Yahyaee \& Syed (2007), Zeitun \& Tian (2007), Weill (2008), and Nunes, Serrasqueiro \& Sequeira (2009). Besides, Majumdar and Chhibber (1999) and Margaritis \& Psillaki (2007) find a positive relationship. To determine the effect of tangibility on profitability, we use the ratio (TANG); it is calculated by dividing the sum of net tangible assets to total assets.

Size: The size will also be included as a determinant of profitability. Currently, Vietnam contains many firms with varying sizes. Due to this, it is interesting to investigate if this variable has any relationship with firm profitability. Yazdanfar \& Öhman (2015) and Goddard, Tavakoli \& Wilson (2005) found a negative relationship between size and profitability, while the results of Chadha \& Sharma (2015) implied that larger firms generally are more profitable. The size was measured as turnover by Yazdanfar \& Öhman (2015), the natural logarithm of total assets by Goddard, Tavakoli \& Wilson (2005) and Chadha \& Sharma (2015). In this study, the author also uses the same measurement with a firm size variable.

Tax: The tax impact on the profitability of a company is difficult to predict because it depends on the principle of tax-deductibility of interest on debt. So, if a company does not take advantage of this principle, we expect a negative effect of tax on profitability. On the contrary, if a company takes advantage of this principle, this impact will be positive or not significant. Zeitun \& Tian (2007) showed a positive effect of tax on profitability. The impact of tax on corporate profitability is highlighted by using the tax ratio in the regression equation. This ratio (TAX) is calculated by dividing the tax paid to earnings before interest and taxes.
Growth opportunities: It is expected that firms having high growth opportunities have a high rate of return because these companies can generate more profits from the investment. Therefore, growth opportunities should positively influence profitability. The positive impact of growth opportunities on profitability is confirmed by most empirical studies such as Zeitun \& Tian (2007), Nunes, Serrasqueiro, \& Sequeira (2009). On the other hand, Margaritis \& Psillaki (2010) find a negative effect only in the French chemical sector. Several measures to calculate growth opportunities for companies exist in literature. But in the context of our analysis, we use the ratio of growth opportunity (GROWTH) which is measured by the change in total assets from one year to another.

\section{Methodology}

The model in order to analyze the impact of debt on corporate profitability is as follows:

$$
\begin{aligned}
& \text { Equation 1: } \\
& \begin{aligned}
\text { Profitability }_{i, t}= & \beta_{0}+\beta_{1} \text { Debt }_{i, t}+\beta_{2} \text { Size }_{i, t} \\
& +\beta_{3} \text { Tang }_{i, t}+\beta_{4} \text { Growth }_{i, t}+\beta_{5} \text { TAX }_{i, t}+\varepsilon_{i, t}
\end{aligned}
\end{aligned}
$$

Where subscript " $i$ " denotes the studied company, and subscript " $t$ " represents the time period. The dependent variable is the ratio of profitability (Profitability). Moreover, (Debt), (Tang), (Size), (TAX), and (Growth) represent the ratios of debt, tangibility, size, tax, and growth opportunities. Finally, the error term is assumed to be independent and identically distributed (iid) which is represented by the term $\left(\varepsilon_{i t}\right)$.

Regarding the effect of non-linearity between debt and profitability, we estimate a quadratic model that takes into account the debt variable squared in the regression equation. Thus, the model to estimate in this context is as follows:

Equation 2:

$$
\begin{aligned}
\text { Profitability }_{i, t}= & \beta_{0}+\beta_{1} \text { Debt }_{i, t}+\beta_{2} \text { Debt }_{i, t}+\beta_{3} \text { Sizeit } \\
& +\beta_{4} \text { Tang }_{i, t}+\beta_{5} \text { Growth }_{i, t}+\beta_{6} \text { TAX }_{i, t}+\varepsilon_{i, t}
\end{aligned}
$$

The null hypothesis of linearity effect is to test: (H0: $\beta_{2}=0$ ). If this hypothesis is rejected, we can conclude the existence of non-linearity between debt and profitability. According to the agency cost theory, the effect of debt on profitability must be positive when $\left(\beta_{1}>0\right)$. And $\left(\beta_{1}+2 \beta_{2}\right.$ Debt $\left._{i, t}>0\right)$. However, if the debt ratio arrives at an adequately high level, this effect can become negative. So, our quadratic specification is consistent with the possibility that the relationship between debt and profitability may not be monotonic, it may switch from positive to negative at a high level of debt. Debt will have a negative impact on profitability when $\left(D e b t_{i, t}<-\beta_{1} / 2 \beta_{2}\right)$. A sufficient condition 
for the inverse U-shaped relationship between debt and profitability to hold is that $\left(\beta_{2}<0\right)$.

We suspect problems of endogeneity in the estimation equation related to the causality of exogenous variables to the dependent variable (especially the debt variable). Therefore, traditional econometric methods such as Ordinary Least Square (OLS), fixed effect, and Generalized Least Square (GLS) do not allow us to obtain efficient estimates of such a model. So, to solve this problem, we introduce the generalized method of moments on panel (GMM) proposed by Arellano \& Bond (1991), Arellano \& Bover (1995) and Blundell \& Bond (1998). This method can provide solutions to simultaneity bias, reverse causality (especially between debt and profitability), and possible omitted variables. Moreover, it can control the individual and temporal specific effects. Indeed, the GMM method is used to solve the problems of endogeneity not only on the debt variable but also for other explanatory variables by using a series of instrumental variables generated by lagged variables.

The model is estimated by two-step GMM. To choose the best model specification, we examined several specifications according to different assumptions about the endogeneity of variables.

\section{Correlation Analysis}

\subsection{Partial and Semi Partial Correlations}

We understand that a partial correlation is a relationship between $\mathrm{x}$ and $\mathrm{y}$ once the shared variance between $\mathrm{x}$ and $\mathrm{x} 2$ has been removed from $\mathrm{x}$ and once the shared variance between $\mathrm{y}$ and $\mathrm{x} 2$ has been removed from $\mathrm{y}$. A semi partial correlation is similar except that we only remove the shared variance between $\mathrm{x}$ and $\mathrm{x} 2$ (i.e., $\mathrm{y}$ remains untouched). Note: Although I've only referenced x2, we can in principle include many control variables as our case will show.

Note that the first variable listed is considered the $y$ variable. All other variables are considered $\mathrm{x}$ variables. Stata reports as many partial and semi partial correlations as there are $\mathrm{x}$ variables. Additionally, Stata reports the squared partial and squared semi partial correlations. These are interpreted as the proportion of shared variance between $\mathrm{y}$ and $\mathrm{x}$ controlling for other $\mathrm{x}$ variables. The partial and semi partial correlations listed for Profitability are the same as what we found above.

\subsection{Correlation between the Variables}

The correlation matrix for the variables has been noted in Table (3). The results show that debt is negatively correlated with profitability, but this negative effect is negligible. Moreover, tangibility has also a negative relationship with all profitability ratios. On the other hand, growth opportunities and tax have a positive correlation with profitability. Looking at the relationship between the independent variables themselves, the results show that multicollinearity is not a problem for the application of analytical techniques.

Table 2: Partial and semi partial correlations

\begin{tabular}{|l|c|c|c|c|c|}
\hline \multirow{2}{*}{ Variable } & Partial & Semipartial & Partial & Semipartial & Significance \\
\cline { 2 - 6 } & Corr. & Corr. & Corr.^2 & Corr.^2 & Value \\
\hline debt & -0.0891 & -0.0752 & 0.0079 & 0.0056 & 0.0041 \\
\hline debt2 & -0.0329 & -0.0277 & 0.0011 & 0.0008 & 0.2894 \\
\hline Size & 0.0948 & 0.0800 & 0.0090 & 0.0064 & 0.0023 \\
\hline tang & 0.0834 & 0.0703 & 0.0070 & 0.0049 & 0.0072 \\
\hline growth & 0.2497 & 0.2166 & 0.0623 & 0.0469 & 0.0000 \\
\hline TAX & 0.0531 & 0.0447 & 0.0028 & 0.0020 & 0.0876 \\
\hline
\end{tabular}

Table 3: Pearson correlation matrix

\begin{tabular}{|l|c|c|c|c|c|c|c|}
\hline & Profitability & debt & debt2 & Size & tang & growth & Tax \\
\hline Profitability & 1.0000 & & & & & & \\
\hline debt & -0.4789 & 1.0000 & & & & & \\
\hline debt2 & -0.4812 & 0.9784 & 1.0000 & & & & \\
\hline Size & 0.0224 & 0.1693 & 0.1540 & 1.0000 & & & \\
\hline Tang & 0.0790 & -0.1460 & -0.1633 & -0.3080 & 1.0000 & & \\
\hline Growth & 0.1812 & 0.0940 & 0.0746 & 0.1877 & -0.2070 & 1.0000 & \\
\hline TAX & 0.0651 & -0.0243 & -0.0316 & 0.0275 & -0.0010 & 0.0213 & 1.0000 \\
\hline
\end{tabular}




\section{Econometric Analysis}

We estimated the effect of debt on profitability for 118 Vietnamese companies for the period 2009 to 2017, by using various representatives of profitability ratios. Moreover, we used two different models (linear and nonlinear) to verify the presence of nonlinearity of this impact. So, the results of the estimation of the GMM method on panel data models with each of the profitability measures are displayed in Table (4) and Table (5).

We can say that all our results are robust for the following reasons: First, the instruments used in our regressions are valid, because the Endogeneity test does not reject the hypothesis of the validity of lagged variables in levels and indifference as instruments. Secondly, we note that there is no second-order auto-correlation of errors for the difference equation because the Hansen J test does not allow rejecting the hypothesis.

We note that debt has an influence on profitability, either in a linear way or in a non-linear way. This finding is inconsistent with Baum, Schäfer \& Talavera (2006) on American industrial companies.

Regarding the control variables, we note that the size of the firms positively affect profitability, which implies that larger firms are generally more profitable. On the other hand, growth opportunities affect positively the profitability; it means that companies have high profitability levels when they have increased growth opportunities and taxes.

According to the linear model, it is observed that the debt variable is negative and significant for profitability ratios (0.139). So, this manifests that debt affects profitability negatively; an increase in the debt ratio of $1 \%$ causes a decrease in corporate profitability by almost $0.14 \%$. These findings support the results obtained by Majumdar \& Chhibber (1999), Eriotis, Frangouli \& VentouraNeokosmides (2002), Goddard, Tavakoli \& Wilson (2005), Rao, Al-Yahyaee \& Syed (2007), Zeitun \& Tian (2007) and Nunes, Serrasqueiro \& Sequeira (2009).

Regarding the impact of debt on profitability according to the quadratic model, we note that debt ratio squared (Debt2) variable is always negative and significant, implying that the null hypothesis of linearity is rejected. So, the significance of the quadratic coefficient confirms the hypothesis of the existence of a non-linearity between debt and profitability. In addition, we report a concave relationship between debt and profitability as the coefficient of debt ratio squared (Debt2) is negative. Hence, this result converges with the agency theory and related findings obtained by Berger \& Bonaccorsi (2006) and Margaritis \& Psillaki (2007).

Table 4: The effect of debt on profitability

\begin{tabular}{|l|c|c|c|c|}
\hline Estimator & POLS(robust) & FE & FGLS & IV-GMM \\
\hline VARIABLES & Profitability & Profitability & Profitability & Profitability \\
\hline Debt & $-0.232^{\star * *}$ & $-0.297^{* * *}$ & $-0.232^{* * *}$ & $-0.139^{* * *}$ \\
\hline & {$[0.015]$} & {$[0.025]$} & {$[0.012]$} & {$[0.028]$} \\
\hline Size & $0.012^{* * *}$ & -0.011 & $0.012^{* * *}$ & $0.017^{* *}$ \\
\hline & {$[0.004]$} & {$[0.012]$} & {$[0.004]$} & {$[0.008]$} \\
\hline Tang & $0.038^{* * *}$ & $-0.138^{* * *}$ & $0.038^{* * *}$ & -0.004 \\
\hline & {$[0.013]$} & {$[0.031]$} & {$[0.013]$} & {$[0.028]$} \\
\hline Growth & $0.070^{* *}$ & $0.057^{* * *}$ & $0.070^{* * *}$ & $0.060^{* * *}$ \\
\hline & {$[0.014]$} & {$[0.007]$} & {$[0.008]$} & {$[0.023]$} \\
\hline TAX & $0.027^{*}$ & 0.008 & $0.027^{*}$ & -0.067 \\
\hline & {$[0.014]$} & {$[0.014]$} & {$[0.016]$} & {$[0.050]$} \\
\hline Constant & $0.103^{* * *}$ & $0.314^{* * *}$ & $0.103^{* * *}$ & 0.036 \\
\hline & {$[0.023]$} & {$[0.071]$} & {$[0.024]$} & {$[0.054]$} \\
\hline Observations & 1,041 & 1,041 & 1,041 & 109 \\
\hline R-squared & 0.293 & 0.202 & & 0.215 \\
\hline Number of id1 & 118 & 118 & \\
\hline Wald/F test (p-value) & 0.0000 & 0.000 & 0.0000 & \\
\hline Hansen J test (p-value) & & & 0.1123 \\
\hline Endogeneity test (p-value) & \multicolumn{3}{|l}{} & 0.3935 \\
\hline Standard errors are in [] & & & \\
\hline
\end{tabular}

Note: ${ }^{*},{ }^{* *},{ }^{* *}$ are significant levels at $10 \%, 5 \%$, and $1 \%$, respectively. 
Table 5: The effect of debt on profitability

\begin{tabular}{|l|c|c|c|c|}
\hline Estimator & POLS (robust) & FE & FGLS & IV-GMM \\
\hline VARIABLES & Profitability & Profitability & Profitability & Profitability \\
\hline Debt & $-0.171^{* *}$ & -0.110 & $-0.171^{* * *}$ & $0.538^{* *}$ \\
\hline & {$[0.070]$} & {$[0.077]$} & {$[0.059]$} & {$[0.235]$} \\
\hline debt2 & -0.063 & $-0.189^{* *}$ & -0.063 & $-0.692^{* * *}$ \\
\hline & {$[0.064]$} & {$[0.074]$} & {$[0.059]$} & {$[0.225]$} \\
\hline Size & $0.012^{* * *}$ & -0.010 & $0.012^{* * *}$ & -0.000 \\
\hline & {$[0.004]$} & {$[0.012]$} & {$[0.004]$} & {$[0.009]$} \\
\hline Tang & $0.036^{* * *}$ & $-0.134^{* * *}$ & $0.036^{* * *}$ & $-0.049^{* *}$ \\
\hline & {$[0.013]$} & {$[0.031]$} & {$[0.013]$} & {$[0.024]$} \\
\hline Growth & $0.069^{* * *}$ & $0.056^{* * *}$ & $0.069^{* * *}$ & $0.054^{* *}$ \\
\hline & {$[0.014]$} & {$[0.007]$} & {$[0.008]$} & {$[0.025]$} \\
\hline TAX & $0.027^{*}$ & 0.008 & $0.027^{*}$ & $-0.087^{*}$ \\
\hline & {$[0.014]$} & {$[0.014]$} & {$[0.016]$} & {$[0.052]$} \\
\hline Constant & $0.093^{* * *}$ & $0.269^{* * *}$ & $0.093^{* * *}$ & 0.017 \\
\hline & {$[0.025]$} & {$[0.073]$} & {$[0.026]$} & {$[0.062]$} \\
\hline Observations & 1,041 & 1,041 & 1,041 & 109 \\
\hline R-squared & 0.294 & 0.208 & & 0.151 \\
\hline Number of id1 & & 118 & 118 & \\
\hline Wald/F test (p-value) & 0.0000 & 0.0000 & 0.0000 & \\
\hline Hansen J test (p-value) & & & & 0.1195 \\
\hline Endogeneity test (p-value) & & & & 0.1146 \\
\hline Standard errors are in [] & & & & \\
\hline
\end{tabular}

Note: ${ }^{*},{ }^{* *},{ }^{* * *}$ are significant levels at $10 \%, 5 \%$, and $1 \%$, respectively.

$$
\begin{aligned}
\text { OptimalDebtRatio } & =\frac{\beta_{1}}{-2 \times \beta_{2}}=\frac{0.538}{-2 \times-0.692} \\
& =0.3887 \approx 38.87 \%
\end{aligned}
$$

From this, experimental evidence shows that the optimal debt ratio is $38.87 \%$. It shows how much the company relies on debt to finance assets. The debt ratio gives users a quick measure of the amount of debt that the company has on its balance sheets compared to its assets. The higher the ratio, the greater the risk associated with the firm's operation. A low debt ratio indicates conservative financing with an opportunity to borrow in the future at no significant risk.

\section{Conclusion}

In this paper, we are interested in the impact of debt on the profitability of Vietnam companies. In other words, this article expands the empirical literature regarding the influence of debt on profitability. There are three essential theories that highlight the influence of debt on corporate profitability, namely: signalling theory, tax theory, and the agency costs theory. Furthermore, the disagreement between researchers observed not only theoretically but also empirically.

To do this, we examined empirically the impact of debt on profitability by using the generalized method of moments (GMM) on an unbalanced panel of 118 Vietnam companies observed over the period 2009 to 2017. Our sample is composed of listed companies on the Vietnamese stock exchange. Moreover, we analyzed only the linear effect of debt on profitability, but also the non-linear effect by estimating a quadratic model which takes into account the squared of the debt variable in the regression equation. According to this study, we can underline that debt has to influence profitability either in a linear way or in a nonlinear way. This finding is inconsistent with that of Baum, Schäfer \& Talavera (2006) and some other studies. 
For potential research, it would be interesting to take into account some reflections. First, it will be interesting to extend this analysis across different components of corporate debt; because, according to most of the studies, contradictory effects have been found. Secondly, we ideally would add new specific variables for companies and sectors, for example, the ownership structure of the corporate capital and the environment in which companies operate. Finally, considering the fact that the relationship between debt and profitability can be non-linear, we can deepen our analysis by using econometric methods that can evaluate the effects of non-linearity as quantile regression and threshold models.

\section{References}

Ali, A., \& Faisal, S. (2020). Capital Structure and Financial Performance: A Case of Saudi Petrochemical Industry. Journal of Asian Finance, Economics, and Business, 7(7), 105-112. https://doi.org/10.13106/jafeb.2020.vol7.no7.105

An, N., \& Tuan, N. (2018). Free cash flow and corporate profitability in emerging economies: Empirical evidence from Vietnam. Economics Bulletin, 38(1), 211-220.

Arellano, M., \& Bond, S. (1991). Some tests of specification for panel data: Monte Carlo evidence and an application to employment equations. The Review of Economic Studies, 58(2), 277-297.

Arellano, M., \& Bover, O. (1995). Another look at the instrumental variable estimation of error-components models. Journal of Econometrics, 68(1), 29-51.

Baum, C. F., Schäfer, D., \& Talavera, O. (2006). The Effects of ShortTerm Liabilities on Profitability: The Case of Germany (No. 635). DIW Discussion Papers.

Berger, A. N., \& Di Patti, E. B. (2006). Capital structure and firm performance: A new approach to testing agency theory and an application to the banking industry. Journal of Banking \& Finance, 30(4), 1065-1102.

Blundell, R., \& Bond, S. (1998). Initial conditions and moment restrictions in dynamic panel data models. Journal of Econometrics, 87(1), 115-143.

Chadha, S., \& Sharma, A. K. (2015). Capital structure and firm performance: Empirical evidence from India. Vision: The Journal of Business Perspective, 19(4), 295-302.

Deloof, M. (2003). Does working capital management affect profitability of Belgian firms? Journal of Business Finance \& Accounting, 30(34), 573-588.

Dinh, H. T., \& Pham, C. D. (2020). The Effect of Capital Structure on Financial Performance of Vietnamese Listing Pharmaceutical Enterprises. Journal of Asian Finance, Economics, and Business, 7(9), 329-340. https://doi.org/10.13106/jafeb.2020. vol7.no9.329

Eriotis, N. P., Frangouli, Z., \& Ventoura-Neokosmides, Z. (2002). Profit margin and capital structure: An empirical relationship. Journal of Applied Business Research, 18(2), 85-88.
Goddard, J., Tavakoli, M., \& Wilson, J. O. (2005). Determinants of profitability in European manufacturing and services: Evidence from a dynamic panel model. Applied Financial Economics, 15(18), 1269-1282.

Himmelberg, C. P., Hubbard, R. G., \& Palia, D. (1999). Understanding the determinants of managerial ownership and the link between ownership and performance. Journal of Financial Economics, 53(3), 353-384.

Kebewar, M. (2012). The effect of debt on corporate profitability: Evidence from French service sector. Available at SSRN 2191075 .

Le, T., Mai, V., \& Nguyen, V. (2020). Determinants of profitability: Evidence from construction companies listed on Vietnam Securities Market. Management Science Letters, 10(3), 523-530.

Majumdar, S. K., \& Chhibber, P. (1999). Capital structure and performance: Evidence from a transition economy on an aspect of corporate governance. Public Choice, 98(3-4), 287-305.

Margaritis, D., \& Psillaki, M. (2007). Capital structure and firm efficiency. Journal of Business Finance \& Accounting, 34(910), 1447-1469.

Margaritis, D., \& Psillaki, M. (2010). Capital structure, equity ownership and firm performance. Journal of Banking \& Finance, 34(3), 621-632.

Mason, R. L., Gunst, R. F., \& Hess, J. L. (2003). Analysis of designs with random factor levels. Statistical Design and Analysis of Experiments with Applications to Engineering and Science (pp. 347-377). New York, NY: John Wiley \& Son.,

Mesquita, J. M. C., \& Lara, J. E. (2002). Capital Structure and Profitability: The Brazilian Case Academy of Business and Administration Sciences Conference. Vancouver, July, 11-13.

Modigliani, F., \& Miller, M. H. (1958). The cost of capital, corporation finance and the theory of investment. The American Economic Review, 48(3), 261-297.

Nguyen, H. T., \& Nguyen, A. H. (2020). The Impact of Capital Structure on Firm Performance: Evidence from Vietnam. Journal of Asian Finance, Economics, and Business, 7(4), 97105. https://doi.org/10.13106/jafeb.2020.vol7.no4.97

Nucci, F., Pozzolo, A., \& Schivardi, F. (2005). Is firm's productivity related to its financial structure? Evidence from microeconomic data. Rivista Di Politica Economica, 95(1), 269-290.

Nunes, P. J. M., Serrasqueiro, Z. M., \& Sequeira, T. N. (2009). Profitability in Portuguese service industries: A panel data approach. The Service Industries Journal, 29(5), 693-707.

Rao, N. V., Al-Yahyaee, K. H. M., \& Syed, L. A. (2007). Capital structure and financial performance: Evidence from Oman. Indian Journal of Economics and Business, 6(1), 1-14.

Simerly, R. L., \& Li, M. (2000). Environmental dynamism, capital structure and performance: A theoretical integration and an empirical test. Strategic Management Journal, 21(1), 31-49.

ul Qayyum, N., \& Noreen, U. (2019). Impact of Capital Structure on Profitability: A Comparative Study of Islamic and Conventional 
Banks of Pakistan. Journal of Asian Finance, Economics and Business, 6(4), 65-74. https://doi:10.13106/jafeb.2019.vol6. no4.65

Vy, N. T. N. (2016). Does profitability affect debt ratio? Evidence from Vietnam listed firms. Journal of Finance \& Economics Research, 1(2), 87-100.

Weill, L. (2008). Leverage and corporate performance: do institutional environment matter? Small Business Economics, $30(3), 251-265$.
Yazdanfar, D., \& Öhman, P. (2015). Debt financing and firm performance: an empirical study based on Swedish data. The Journal of Risk Finance, 16(1), 102-118.

Zeitun, R., \& Tian, G. G. (2007). Capital structure and corporate performance: Evidence from Jordan. Australasian Accounting, Business and Finance Journal, 1(4), 40-61. 